\title{
Agricultores familiares no Vale do Paraíba Paulista:
}

entre a produção e o consumo de alimentos

\author{
Family farmers in Vale do Paraíba, São Paulo: \\ between food production and consumption
}

Camila Benjamim Vieira ${ }^{1}$

A categoria "agricultor familiar" mobiliza, não de forma homogênea, relações entre a natureza, produção de alimentos e reprodução da vida, que, no rural e urbano transformado, resiste, adapta-se e modifica suas formas produtivas e de consumo. A industrialização, ao distanciar alimento e natureza, conforme afirma Jean-Pierre Poulain em Sociologias da Alimentação (2004), oculta variáveis simbólicas que reverberam nas práticas alimentares. Nos interessa como esse movimento impacta também produtores de alimentos.

Aqui apresento um recorte da pesquisa que tem o objetivo de analisar sociologicamente como agricultores familiares mobilizam a categoria valor (construto teórico, simbólico e social) correlacionada à alimentação. Sobretudo, quais variáveis envolvem a identificação dos agentes de sua produção como alimento. Através de entrevistas, observações de discursos e ações (falas sobre a alimentação e refeições), a pesquisa de campo se desenvolve em três cidades do Vale do Paraíba (SP), acompanhando quatro famílias posicionadas diferentemente nos espaços sociais.

Uma breve caracterização sobre elas: a primeira é produtora de orgânicos, plantam frutas, legumes e verduras (FLV) e criam galinhas. Comercializam em feiras e com cestas, porém a renda principal não é da agricultura. Relatam que possuem "tendência" de consumir o que plantam e o que "encontram" de orgânico no mercado; a segunda tem na agricultura a principal fonte de renda, mas além de plantarem FLV, também atuam como atravessadores em comércio atacadista. Possuem um ponto de venda na propriedade e comercializam no centro da cidade (carrinho de mão), além de entregarem para restaurantes. Não costumam almoçar e comem "qualquer coisa", e a "fome" é um discurso recorrente nas falas do casal; a terceira família, de assentados da reforma agrária, também se sustentam com a agricultura (FLV). Escoam em supermercados, atacadistas, mercados locais e institucionais. Quando necessário, compram marmita para o almoço e possuem o hábito de consumir produtos ultraprocessados. Na quarta família, também de assentados, quem trabalha na horta (FLV) é a filha do meio do casal, sendo que a agricultura não corresponde à renda principal da família. O escoamento da produção é feito em mercados institucionais, por encomendas e mercearias. Afirmam que "procuram ter uma alimentação saudável", dando preferência para saladas e um baixo consumo de "carne".

A incursão inicial no campo permitiu observar que, para os agentes, a alimentação é íntima e privada, sendo difícil acessar os discursos e momentos dela. Já o cruzamento dos dados nos levou a uma correlação inesperada (comparada à literatura sobre subsistência): conforme aumenta a dependência econômica da família à agricultura, mais distante fica a identificação da produção 
como alimento (para consumo), e ela é tida como produto e renda que levará à compra desses. E de maneira inversa: os que menos dependem da agricultura como fonte de renda aproximam a identificação de sua produção para consumo.

Palavras-chave: produção e consumo alimentar; agricultura familiar; Vale do Paraíba (SP); sociologia econômica.

Keywords: food production and consumption; family farming; Vale do Paraíba; economic sociology.

1 Doutoranda em Sociologia na Universidade Federal de São Carlos e bolsista Capes. 